\title{
Człowiek kultury druku w świecie przyszłości - kino science fiction wobec teorii środków przekazu Marshalla McLuhana
}

\begin{abstract}
Kowalczyk Marcin, Człowiek kultury druku w świecie przyszłości - kino science fiction wobec teorii środków przekazu Marshalla McLuhana [Man of Print Culture in the Future World - Science Fiction Cinema and Marshall McLuhan's Media Theory]. „Przestrzenie Teorii” 32. Poznań 2019, Adam Mickiewicz University Press, pp. 239-255. ISSN 1644-6763. DOI 10.14746/pt.2019.32.12.

This article shows the way of presenting the characters who represent print culture in science fiction cinema. All the printed artifacts, like literature, books and letters, are defined according to Marshall McLuhan's media theory. The analysis is based mostly on the movie Her (dir. Spike Jonze, 2013) and discusses how SF movies adapt and transform the twentieth-century predictions concerning print as a medium. This approach allows us to avoid a simple interpretation of the problem, where books or print become merely a sign of civilization that has passed. Furthermore, McLuhan's theory helps effectively reveal the complex motivations of the characters who are shaped by a specific medium.
\end{abstract}

KEYWORDS: Marshall McLuhan, science fiction cinema, print culture, media theory

Rewolucja cyfrowa zapoczątkowała szereg zmian, które miały (i wciąż maja) niebagatelny wpływ na literaturę. Zmiany te możemy rozważać na wielu poziomach: od fizycznych przekształceń książki drukowanej, poprzez obecność nowych strategii w samym akcie tworzenia, aż po ostateczny wymiar artystyczny dzieła literackiego ${ }^{1}$. W ostatnich dziesięcioleciach sporo jest głosów, których ton dobrze oddaje tytuł książki Alvina Kernana z 1990 roku, The Death of Literature ${ }^{2}$. Wsłuchując się w nie, dochodzimy

${ }^{1}$ Znakiem tych zmian w obrębie wskazanych poziomów jest literatura elektroniczna. Scott Rettberg wskazuje, na czym polega atrakcyjność tego typu pisarstwa: „nowe możliwości podłączonego do sieci komputera jako medium: łatwe włączanie multimediów w teksty literackie, programowalna natura cyfrowych wytworów literackich, możliwość dystrybucji w rodzącej się globalnej sieci i nowe rejestry reprezentacji semantycznych”. Zob. tegoż, Budowanie wspólnoty wokót literatury elektronicznej, „Teksty Drugie” 2015, nr 3, s. 135.

${ }^{2}$ Zob. A. Kernan, The Death of Literature, New Haven and London 1990. Autor wiaże tytułowa śmierć literatury z ogólnym upadkiem wartości. W takim ujęciu dzieło literackie (zwykle zaliczane do klasyki) jest nośnikiem pewnego konserwatywnego etosu. Jednak na problem można spojrzeć z wielu stron - to, co dla Kernana jest „upadkiem”, „śmiercią, dla innych badaczy stanowi nieuchronne przekształcenie medium w kolejnych fazach rozwoju kultury. O wskazanych problemach piszą m.in.: R.B. Schwartz, After the Death of Literature, Edwardsville 1992; J. Gomez, Print is Dead. Books in Our Digital Age, London-New YorkMelbourne-Hong Kong 2008; T. Striphas, The Late Age of Print. Everyday Book Culture 
do wniosku, że śmierć literatury, czy - wychodząc poza rozprawę Kernana - pisma i druku, jest bliska i nieuchronna ${ }^{3}$. Ted Striphas wskazuje, że w samych Stanach Zjednoczonych czytelnicy wydają się porzucać książki w alarmującym tempie miliona ludzi rocznie ${ }^{4}$. Mounir Ben Zid omawiając stanowiska badaczy wobec wspomnianego kryzysu, konstatuje: „Przyszła misją literatury i racją bytu nie jest służenie ustalonemu porządkowi społecznemu i jego wartościom, ale raczej unikanie sposobu myślenia, który redukuje życie do zwykłych kalkulacji i zimnej logiki”. W tej nieco idealistycznej deklaracji pobrzmiewa przekonanie, że literature powinien ocalić jej artystyczny i nonkonformistyczny wymiar. Jednak nawet jeśli uda się choćby częściowo zrealizować ów postulat, to - jak podkreśla Jeff Gomez wielu pisarzy nie przetrwa przejścia $\mathrm{w}$ formę cyfrowa ${ }^{6}$. Tutaj otwiera się oczywiście szeroka przestrzeń do spekulacji, jak docelowo owa „forma cyfrowa" miałaby wyglądać ${ }^{7}$. Nie podejmując tych rozważań, zauważmy, że zarysowany tu sposób pojmowania kondycji literatury (prawdziwy lub nie) jest istotnym elementem kultury współczesnej ${ }^{8}$. Frazy o powolnej śmierci książki, pisma, druku, nie brzmią dziś jak kasandryczne proroctwa, lecz jak oczywisty, bezalternatywny scenariusz przyszłości ${ }^{9}$.

Jak już wspomnieliśmy powyższa diagnoza łączona bywa zwykle z wejściem kultury w epokę cyfrową w latach osiemdziesiątych XX wieku. Jednak zmiany, które doprowadziły do istotnego obniżenia statusu druku, a co za tym idzie literatury, zaczęły się dużo wcześniej - wraz z pojawieniem

from Consumerism to Control, New York 2009; P. Swirski, From Literature to Biterature: Lem, Turing, Darwin, and Explorations in Computer Literature, Philosophy of Mind, and Cultural Evolution, Montreal 2013.

${ }^{3}$ Zaznaczyć należy, że są i głosy przeciwne. Agnieszka Przybyszewska, badając problem przyszłości książki, konstatuje, że owa apokaliptyczna wizja jej śmierci wydaje się przesadzona. Powołując się na liczne przykłady, mówi wręcz o renesansie tego medium i jego ciekawych przekształceniach. Zob. tejże, Między materialnościa a wirtualnościq. Przypadek ksiażek rzeczywistości rozszerzonej, „Teksty Drugie” 2014, nr 3, s. 91.

${ }^{4}$ T. Striphas, dz. cyt., s. 15 (wszystkie cytaty z książek anglojęzycznych podaję we własnym przekładzie - M.K.).

${ }^{5}$ B.M. Zid, Literature of the Future and the Future of Literature, "Studies in Literature and Language" 2016, t. 12 , nr 4, s. 5.

${ }^{6}$ J. Gomez, dz. cyt., s. 186.

${ }^{7}$ Różne możliwości ewolucji książki wskazują m.in.: S. Rettberg, dz. cyt.; A. Przybyszewska, dz. cyt.

${ }^{8}$ Zaznaczyć jednak należy, że kryzys książki drukowanej jako środka przekazu wcale nie musi oznaczać spadku czytelnictwa. Badacze wskazują bowiem, że wraz z ewolucją mediów zmieniają się też sposoby uczestnictwa w kulturze. Zob. M. Maryl, Kulturowa piśmienność: projekt badań totalnych kultury literackiej, „Teksty Drugie” 2015, nr 3, s. 9-29.

${ }^{9}$ Znaczacy w tym kontekście wydaje się fakt, że zwolennikiem tej tezy jest uznany pisarz i futurolog Jacek Dukaj, który daje temu wyraz nie tylko w utworach literackich, ale przede wszystkim w swej publicystyce: zob. tegoż, Po piśmie, Kraków 2019. 
się radia, telefonu czy kina (później telewizji) ${ }^{10}$. W takim ujęciu komputer osobisty oraz Internet stanowią tylko kolejne stadium ewolucji środków przekazu. Jednym z myślicieli, którzy uważnie przyglądali się tym zmianom był Marshall McLuhan. I choć badacz zmarł właściwie w przededniu ery cyfrowej (1980), niektóre jego spostrzeżenia dotyczące środków przekazu i ich roli z powodzeniem nadają się do opisu współczesnej rzeczywistości komunikacyjnej ${ }^{11}$. Przedstawmy zatem pokrótce te, które w niniejszym tekście zostaną wykorzystane jako narzędzie interpretacyjne.

Jedna z najbardziej znanych tez kanadyjskiego badacza mówi, że sam środek przekazu jest przekazem (the medium is the message) ${ }^{12}$. McLuhan wyjaśnia to w sposób następujący: „"przekazem» dowolnego środka przekazu lub techniki jest [...] zmiana skali, tempa lub wzorca, jaka ten środek wprowadza w ludzkie życie" ${ }^{13}$. Według badacza nieistotna jest zatem jednostkowa treść przekazu, z samego posługiwania się pismem bowiem wynika zmiana w sposobie myślenia, co przekłada się na chęć porządkowania przestrzeni, rozwija logiczne myślenie, jest powodem specjalizacji ${ }^{14}$. Tak więc „piśmienność zmienia nasze nawyki, emocje i percepcję"15. Stąd literatura (u McLuhana często synonimizowana z pismem, drukiem lub po prostu alfabetem fonetycznym) jako medium całkowicie przeformułowała kulturę i wpłynęła na kierunek jej ewolucji. Zrodziła człowieka indywidualnego, oderwanego od pierwotnej wspólnoty. Agnieszka Ogonowska, analizując myśl McLuhana, podkreśla znaczenie tej diagnozy:

[...] wraz z wynalezieniem pisma pojawia się idea przestrzeni prywatnej, która w praktyce daje o sobie znać na przykład w prawie do poufności korespondencji. Słuchanie odbywa się w przestrzeni społecznego (publicznego) biesiadowania; czytanie i pisanie wymaga samotności, izolacji, wyciszenia, prywatności ${ }^{16}$.

${ }^{10}$ Świadomie unikamy odwołań do McLuhanowskiego podziału środków przekazu na zimne i gorące, ponieważ problem ten sytuuje się poza ramami niniejszej analizy.

${ }^{11}$ Zob. K. Loska, Dziedzictwo McLuhana. Między nowoczesnościq a ponowoczesnościa, Kraków 2001; P. Levinson, Digital McLuhan. Guide to the Information Millennium, London 2004; McLuhan's Global Village Today. Transatlantic Perspective, red. C. Birkle, A. Krewani, M. Kuester, Vermont 2014.

${ }^{12}$ Stwierdzenie to pojawia się wielokrotnie w wielu pracach Marshalla McLuhana. W niniejszym artykule odwołujemy się przede wszystkim do czterech z nich: M. McLuhan, Galaktyka Gutenberga, przeł. A Wojtasik, Warszawa 2017 (pierwsze wyd. Toronto 1962); tegoż, Zrozumieć media. Przedtużenie człowieka, przeł. N. Szczucka, Warszawa 2004 (pierwsze wyd. New York 1964); M. McLuhan, Q. Fiore, The Medium is the Message: An Inventory of Effects, Corte Madera 2001 (pierwsze wyd. New York 1967); M. McLuhan, Wybór tekstów, red. E. McLuhan, F. Zingrone, przeł. E. Różalska, J.M. Stokłosa, Poznań 2001.

${ }^{13}$ M. McLuhan, Zrozumieć media..., s. 40.

${ }^{14}$ M. McLuhan, Kultura bez pisma, [w:] Wybór tekstów..., s. 434.

${ }^{15}$ M. McLuhan, Zrozumieć media..., s. 135.

${ }^{16}$ A. Ogonowska, Twórcze metafory medialne, Kraków 2010, s. 102. 
Jednak według McLuhana ponad dwa tysiące lat obecności pisma w kulturze Zachodu dobiega końca. Już w latach sześćdziesiątych kanadyjski badacz konstatował, że nowe środki przekazu, takie jak telefon, radio i telewizja w znacznym stopniu naruszyły zbudowane na nim wartości ${ }^{17}$. Pół wieku później ów koniec wydaje się wielu jeszcze bardziej prawdopodobny. Aleksander Radwański uważa, że przewidywania autora Galaktyki Gutenberga już się sprawdziły:

McLuhan twierdził, że będziemy inaczej postrzegać świat, bo inne przekaźniki kształtować będą naszą percepcję. I tak się stało, chociaż wielu ludziom mogło to umknać, ponieważ przejawy nowej, elektronicznej rzeczywistości stały się widoczne dopiero z większego dystansu ${ }^{18}$.

Zmierzch druku pociaga za sobą poważne konsekwencje. Jedna z McLuhanowskich metafor mówi, że świat staje się „globalną wioską" ${ }^{\text {. Nowe }}$ formy komunikacji i odejście od medium literatury oraz - szerzej - druku, tworzą „elektroniczną współzależność”, która wprowadza rewolucję nie mniejszą od tej, jaką wcześniej zapoczątkowało pismo. McLuhan określa ją terminem „retrybalizacja” (retribalization) i opisuje istotę tego procesu w sposób następujący: „media elektroniczne zmniejszają świat do poziomu plemienia lub wioski, gdzie wszystko dzieje się dla wszystkich w tym samym czasie: wszyscy o wszystkim wiedzą i uczestniczą w tym, co dzieje się w chwili, gdy ma to miejsce" ${ }^{20}$. Walter J. Ong rozwijając myśli MacLuhana, mówi tu o „oralności wtórnej” ${ }^{21}$. Tak jak wynalezienie alfabetu fonetycznego i druku umożliwiło przejście od człowieka plemiennego do indywidualisty ${ }^{22}$, tak media elektroniczne proces ten odwracają. Nowa elektroniczna współzależność odtwarza świat pod postacia globalnej wioski ${ }^{23}$. Człowiek z obywatela staje się nomada, szczęście zastępuje przyjemnościa, prawdę pasja, a sztukę marzeniem ${ }^{24}$. Proces ten, zdaniem kanadyjskiego badacza, niesie ze soba

${ }^{17}$ M. McLuhan, Zrozumieć media..., s. 131.

${ }^{18}$ A. Radwański, Szanujmy McLuhana, „Bibliotekarz” 1998, nr 10, s. 4.

${ }^{19}$ Genezę powstania metafory przybliża syn badacza, Eric McLuhan. Zob. tegoż, The Source of the Term, "Global Village", "McLuhan Studies" 1999, Issue 2, <http://projects.chass. utoronto.ca/mcluhan-studies/v1_iss2/1_2art2.htm> [dostęp: 25.08.2019].

${ }^{20}$ M. McLuhan, The Agenbite of Outwit, "McLuhan Studies" 1999, Issue 2 (pierwsza publ. 1963), <http://projects.chass.utoronto.ca/mcluhan-studies/v1_iss2/1_2art6.htm> [dostęp: 25.08.2019].

${ }^{21}$ W.J. Ong, Oralność i piśmienność: Stowo poddane technologii, przeł. J. Japola, Lublin 1992, s. 23.

${ }^{22}$ M. McLuhan, Zrozumieć media..., s. 77.

${ }^{23}$ M. McLuhan, Galaktyka Gutenberga..., s. 88.

${ }^{24}$ Korzystam tu z klasyfikacji sporządzonej przez Lewisa H. Laphama, który, opierając się na uważnej lekturze dzieł McLuhana, przyporządkowuje pismu i elektronicznym środ- 
wiele pozytywnych aspektów. Jak podkreśla Kerstin Schmidt, McLuhan dostrzega w retrybalizacji i mediach elektronicznych możliwość połączenia wyalienowanych i zagubionych jednostek ze współczesnymi im czasami25.

Jednak człowiek druku nie znika nagle, pozostaje wciąż obecny pośród wytworów kultury cyfrowej (i chyba zawsze tak będzie). Jego zmierzch jest powolny, a naturalną kroniką odejścia dzieła szkicujące panoramy przyszłości, a więc także te reprezentujące kino science fiction. Wszak jednym z konstytutywnych elementów tego gatunku jest mówienie o tym, co nadejdzie. Przy czym punktem wyjścia bywa zwykle współczesny twórcom stan kultury i nauki. Sean Redmond posuwa się jeszcze dalej, mówiąc, że kino SF „może obejmować zwykłe «kopiowanie» istniejących relacji społecznych i kulturowych, tak, aby to, co widzowie widzą i słysza, częściowo przypominało świat, jakiego doświadczają na co dzień”"26. Oczywiście kino science fiction nie pełni wobec rzeczywistości wyłącznie służebnej roli. W pewien sposób bowiem, jak podkreśla Jay P. Teolette, przewidując przyszłość, jednocześnie ją umożliwia ${ }^{27}$. Jeśli więc przyjmiemy, że istotnym elementem przełomu wieków XX i XXI stała się zmiana komunikacyjnego paradygmatu, wiążąca się ze zmierzchem druku, warto zbadać, w jaki sposób temat ten przeniknął do kina $\mathrm{SF}^{28}$. W niniejszym tekście zawężymy nieco ten problem, skupiając się na bohaterach przedstawianych jako ludzie/istoty kultury druku. Drugim, niejako naturalnym elementem wywodu stanie się połaczenie statusu literatury i procesu retrybalizacji, który zgodnie z przewidywaniami McLuhana powinien być istotnym elementem społeczeństwa przyszłości ${ }^{29}$. Głównym przedmiotem analizy będzie wielokrotnie nagradzany film $\mathrm{Her}$ Spike'a Jonze'a z 2013 roku $^{30}$. Wydaje się bowiem, że w obrazie tym teoria

kom przekazu określone (często przeciwstawne) zestawy pojęć. Zob. tegoż, Wprowadzenie do wydania MIT Press. Wieczna teraźniejszość, [w:] M. McLuhan, Zrozumieć media..., s. 26-27.

${ }^{25}$ K. Schmidt, Radio Voices: Reflections on McLuhan's Tribal Drum, [w:] McLuhan's Global Village Today..., s. 120.

${ }^{26}$ S. Redmond, Liquid Metal. The Science Fiction Film Reader, New York 2007, s. 2.

${ }^{27}$ J.P. Teolette, Science Fiction Film, Cambridge 2004, s. 25-32. Nie będziemy tu omawiali innych uwikłań gatunkowych kina science fiction. Interesować nas będzie tylko jego potencjał prognostyczny.

${ }^{28} \mathrm{Ma}$ on również swoje miejsce w literaturze science fiction. Różne warianty podejścia do książki w kontekście utopii w literaturze SF przedstawia Andrzej Dróżdż. Zob. tegoż, Od Liber mundi do hipertekstu. Ksiażka w świecie utopii, Warszawa 2009.

${ }^{29}$ Podejście McLuhana i próbę pokazującą aktualność jego teorii opisują m.in. prace: A. Radwański, dz. cyt., s. 3-6; K. Loska, dz. cyt.; P. Levinson, dz. cyt.; McLuhan's Global Village Today...

${ }^{30}$ Obraz zdobył między innymi Nagrodę Akademii Filmowej, Złoty Glob i nagrodę Saturn za najlepszy scenariusz, a także uzyskał kilka innych nagród branżowych i ponad dwadzieścia nominacji. 
środków przekazu McLuhana w pełni ujawni swą przydatność jako narzędzie interpretacyjne ${ }^{31}$.

Podkreślmy, że szeroko rozumiany druk traktujemy tu jako medium zgodnie z ustaleniami kanadyjskiego badacza. Unikamy zatem strategii interpretacyjnej, w której omawiany środek przekazu staje się po prostu znakiem przeszłości. Jest to istotna uwaga, ponieważ już pobieżny rzut oka na kino science fiction ostatnich trzydziestu lat rodzi pokusę, by mówić o prostej zależność między literaturą a stopniem rozwoju technologicznego. Światy przyszłości są zwykle przestrzeniami wizualno-akustycznymi, w których książka łączy się z tym, co stare i przebrzmiałe. Czasem jest ona niepożądana i groźna jak w Equilibrium (reż. Kurt Wimmer, 2002) ${ }^{32}$, a innym razem odsyła do konserwatywnego zdrowego rozsądku umieszczonego wśród książek bohatera (Deckard w Blade Runnerze 2049, reż. Denis Villeneuve, 2017). Krótko mówiąc, w takim ujęciu książka pełniłaby tę samą rolę, co „rzymska grzywka” w znanym szkicu Rolanda Barthes'a ${ }^{33}$ traktującym o filmie Juliusz Cezar (Julius Caesar, reż. J.L. Mankiewicz, 1953) - byłaby prostym i łatwo rozpoznawalnym dla odbiorcy znakiem kultury, która przeminęła.

W naszym ujęciu książce czy listowi bliżej wszakże do artefaktu kulturowego definiowanego przez Anetę Gorodecką w następujący sposób:

Artefakt wskazuje kierunek myślenia, który biegnie od świata materii do świata wiedzy o sztuce i literaturze, od świata rzeczy do wiedzy humanistycznej. Może jednocześnie ucieleśniać preferencje, wartości i normy społeczne $[\ldots]^{34}$.

Odwołując się do McLuhana, należałoby wszakże rozszerzyć tę definicję o aspekt sprawczości. Książka bowiem nie tylko ucieleśnia, ale też umożliwia, czy wręcz stwarza określoną rzeczywistość. Film Jonze’a jest tu dobrym przykładem.

Obraz traktuje o miłości, która rodzi się między głównym bohaterem, Theodorem Twomblym, a jego systemem operacyjnym (sztuczną inteli-

${ }^{31}$ Próbę wykorzystania teorii McLuhana jako narzędzia interpretacyjnego podją Artur Skweres. Zob. tegoż, McLuhan's Galaxies: Science Fiction Film Aesthetics in Light of Marshall McLuhan's Thought, Berlin 2019.

${ }^{32}$ Taki sposób podejścia do książki jest charakterystyczny dla światów antyutopijnych, w których „książka staje się dla człowieka pretekstem do upominania się o utraconą wolność i prywatność". Zob. A. Dróżdż, dz. cyt., s. 347.

${ }^{33}$ Zob. R. Barthes, Rzymianie w filmie, [w:] Mitologie, przeł. A Dziadek, Warszawa 2008, s. 47-49. Francuski badacz omawia tu film Juliusz Cezar J.L. Mankiewicza, wskazując, że twórcy uczynili grzywkę znakiem „rzymskości”. Jak pisze Barthes: „Ułożony na czole kosmyk daje pewność i nikt nie może wątpić, że oto znajduje się w dawnym Rzymie”. Zob. tamże, s. 47.

${ }^{34}$ A. Gorodecka, Artefakt kulturowy w humanistyce, „Przestrzenie Teorii” 2015, nr 23, s. 67 . 
gencja) o imieniu Samantha. Z pozoru więc eksploatuje motyw związku człowieka z maszyną wielokrotnie dyskutowany przez szeroko rozumiany nurt SF. Nie dziwi więc fakt, że wątek ten bywa najczęściej podnoszony w recenzjach filmu. Mark Kermode sytuuje obraz Jonze'a w tradycji dzieł takich, jak Dziewczyna z komputera (Weird Science, reż. John Hughes, 1985) czy Łowca androidów (Blade Runner, reż. Ridley Scott, 1982) oraz sprowadza relację bohatera i AI do odmiany współczesnego romansu ${ }^{35}$. Nieco dalej idzie Richard Brody, pisząc o Faustycznym targu, w którym w zamian za zgodę na fizyczną samotność, bohater otrzymuje dar współczującej rozmowy i wglądu w zakamarki duszy ${ }^{36}$. Kolejni recenzenci („New York Times”, „The Atlantic”, „The Hollywood Reporter”, „Filmweb”) ${ }^{37}$ również eksponuja wątek samotności człowieka w zdominowanym przez technologię świecie, podkreślając związek z Samanthą.

Wydaje się, że teksty te omawiają ledwie część znaczeniowego potencjału niezwykle ciekawej propozycji Jonze’a. Jeśli bowiem spojrzymy na Her przez pryzmat zarysowanych wyżej twierdzeń McLuhana, film stanie się ciekawym przyczynkiem do analizy przenikania się dwóch medialnych paradygmatów. W takim ujęciu wątek romansowy okaże się wtórny wobec kreacji głównych bohaterów jako istot druku, który determinuje ich zachowania i wybory. Zaznaczmy jednak, że przedmiotem niniejszych wywodów nie jest wiążąca diagnoza przyszłości w kontekście teorii i przewidywań kanadyjskiego medioznawcy, lecz wpływ jego myśli na kino science fiction i przydatność teorii jako narzędzia interpretacyjnego.

Zacznijmy zatem od Theodora, który jest pisarzem obdarzonym talentem i empatia. W niedalekiej przyszłości, gdzie druk i pismo są rzadkościa, tworzy on listy na zamówienie. Ostateczną formę jego pracy stanowi odręcznie napisany tekst (choć i on jest pewnego rodzaju imitacją wygenerowana przez komputer). Za swoje prace mężczyzna jest podziwiany, chwalony, co daje mu poczucie wyjątkowości. Niestety w życiu osobistym nie wiedzie mu

${ }^{35}$ M. Kermode, "Her"- review, "The Guardian” 2014.02.16., <https://www.theguardian. com/film/2014/feb/16/her-spike-jonze-joaquin-phoenix-review> [dostęp: 20.08.2019].

${ }^{36}$ R. Brody, Ain't Got No Body, "The New Yorker" 2013.12.19., <https://www.newyorker. com/culture/richard-brody/page/72> [dostęp: 21.08.2019].

${ }^{37}$ M. Dargis, Disembodied, but, Oh, What a Voice, "The New York Times" 2013.12.17., <https://www.nytimes.com/2013/12/18/movies/her-directed-by-spike-jonze.html> [dostęp: 21.08.2019]; Ch. Orr, Why Her Is the Best Film of the Year, "The Atlantic" 2013.12.20., <https:// www.theatlantic.com/entertainment/archive/2013/12/why-em-her-em-is-the-best-film-of-the-year/282544/> [dostęp: 21.08.2019]; T. McCarthy, „Her”: Film Review, “The Hollywood Reporter" 2013.12.10., <https://www.hollywoodreporter.com/review/her-film-review-648073> [dostęp: 21.08.2019]; B. Staszczyszyn, Miłość-niemożliwy projekt, „Filmweb” 2014.01.23., <https:// www.filmweb.pl/review/Mi\%C5\%820\%C5\%9B\%C4\%87+\%E2\%80\%93+niemo\%C5\%BCliwy+projekt-15291> [dostęp: 21.08.2019]. 
się już tak dobrze: właśnie rozwodzi się z żoną i nie może nawiązać relacji z żadną inną kobietą. Czuje się zagubiony, nieprzystosowany do rzeczywistości. W listach, które sprzedaje, wspomina o miłości, przywiązaniu, relacjach z innymi ludźmi, słowem o wszystkim, do czego sam tęskni. Jonze subtelnie kreśli obraz człowieka nieszczęśliwego, choć wiodącego wygodne życie w spokojnej i stabilnej futurystycznej metropolii. Bohater jest oczywiście beneficjentem wygód, które niesie ze sobą świat przyszłości. Jednak owe podstawowe technologiczne ułatwienia dotyczące dostępu do informacji czy możliwość wykonywania pracy zdalnej, które Paul Levinson określa mianem „osobistej epoki cyfrowej” (personal digital age) ${ }^{38}$, nie wpływają na jego sytuację egzystencjalna.

Theodor Twombly zatem spełnia wszystkie warunki wskazane przez McLuhana, a charakteryzujące człowieka pisma: chce zbudować trwały związek (najlepiej małżeństwo), dąży do szczęścia, ma poczucie indywidualności, prawda jest dla niego ważna. Niestety żyje w świecie ery elektronicznej, w którym, przypomnijmy za Agnieszką Ogonowska, „relacjami społecznymi na powrót rządza: solidarność, wspólnotowość, potrzeba zaangażowania i budowania tożsamości grupowej”39. Theodor nie partycypuje w kulturze globalnej wioski. Woli swój mikrowszechświat: pracę i ascetyczne mieszkanie. Tam konserwuje własny indywidualizm. Nie chce być McLuhanowskim „człowiekiem kosmicznym - obywatelem świata" ${ }^{40}$. Choć perspektywę globalną ma na wyciagnięcie ręki, nie jest nią zainteresowany.

O tym, że Twombly uosabia człowieka kultury druku, widz jest informowany kilkakrotnie: bohater pracuje jako pisarz w otoczeniu książek, wciąż lubi wydawnictwa oferujące tradycyjny druk, jego żona również pisała (kiedyś wzajemnie czytali swe dzieła, dzieląc się uwagami). Słowo pisane zajmuje więc centralne miejsce w życiu Theodora. Protagonista ogląda świat przez pryzmat tego właśnie środka przekazu.

Wielokrotnie obserwujemy bohatera wśród innych ludzi, już to na ulicy, już to w metrze. Tam jego samotność i niedopasowanie sa dużo bardziej widoczne niż w skapo umeblowanym mieszkaniu. Literatura, pismo, druk tutaj traktowane jako przemijające medium - ukształtowawszy Theodora, uniemożliwiają mu uczestnictwo $\mathrm{w}$ procesie retrybalizacji. Bohatera nie interesuja bowiem sprawy globalnej wioski, nie jest zaangażowany w żadną formę kolektywnej działalności. Oczywiście zgodnie z teorią McLuhana zaangażowanie takie powinno przyjać formę dobrowolnej partycypacji. Dlatego w świecie wykreowanym przez Jonze'a nikt nie zakazuje obcowania z pismem, drukiem. Nie jest to świat z przywoływanego już Equilibrium,

${ }^{38}$ P. Levinson, dz. cyt., s. 12.

${ }^{39}$ A. Ogonowska, dz. cyt., s. 104.

${ }^{40}$ M. McLuhan, Kultura bez pisma, [w:] Wybór tekstów..., s. 433. 
w którym literatura dosłownie stoi na drodze budowy zunifikowanego społeczeństwa, które można osiagnąć przez całkowite i przymusowe jej wyeliminowanie, jako jednego z rozsadników wirusa indywidualności. Żeby w pełni wyjaśnić podobieństwa między społeczeństwem w Her a myślą McLuhana, posłużmy się konstatacją Krzysztofa Loski. Badacz wskazuje, że:

Wizja globalnej wioski nie ma wiele wspólnego z projektem państwa totalitarnego, jest raczej romantyczną utopią czy też metaforą idealnego społeczeństwa, w którym jedność nie oznacza uniformizacji, spójność - centralizacji, zaś zgoda nie jest wynikiem narzuconych poglądów (ani nawet consensusu) ${ }^{41}$.

Świat, w którym egzystuje Theodor, choć zarysowany dość powierzchownie, wydaje się spełniać powyższe kryteria. Nie ma w nim przemocy, problemów, życie wydaje się spokojne i pozbawione trosk. Jonze odchodzi od efektownych kreacji przestrzeni. Idzie pod prąd tradycji, w której najlepsze filmy SF za sprawą efektów specjalnych pokazywały widzom to, czego jeszcze na ekranie nie widzieli ${ }^{42}$. Kyle Vanhemert słusznie wskazuje, że technologia rozwinęła się tu do takiego stopnia zaawansowania, że nie musi już wyglądać jak technologia ${ }^{43}$. Jednak człowiek pisma chce osiagnąć indywidualne szczęście, nie zadowalaja go doraźne przyjemności. Spokój utożsamia ze stagnacja, bezpieczeństwo z nudą. Na nic zdaje się też ucieczka w hedonizm. Kiedy Twombly próbuje zaznać przyjemności, korzystając z sex chatu, chwilowe odprężenie osiagnięte za pomocą masturbacji, tylko pogłębia jego frustrację. Czuje się bowiem wykorzystany przez wirtualną partnerkę, która znienacka prosi, by podczas „stosunku” dusił ją wyobrażonym zdechłym kotem.

Wszystko ulega zmianie, gdy nieszczęśliwy pisarz instaluje na swoim komputerze inteligentny system operacyjny. AI (Artificial Intelligence), Samantha, wydaje się spełnieniem jego marzeń - okazuje się bystra, wrażliwa, dowcipna. Co zaskakujące, reżyser już od samego początku czyni ją istota zakorzenioną w druku. Pierwszą czynnością jaką wykonuje Samantha, jest bowiem przeczytanie książki i wybranie imienia. Reżyser wyraźnie daje do zrozumienia, że bohaterka ${ }^{44}$ wpisuje się we wrażliwość Theodora. Wszak i on w scenie otwierajacej film pracuje nad jednym ze swoich poruszających listów. Ponadto tytułowa „ona” na każdym kroku podkreśla swoją indywidu-

${ }^{41}$ K. Loska, dz. cyt., s. 53.

${ }^{42}$ K.M. Booker, Alternate Americas: Science Fiction Film and American Culture, Westport-Connecticut-London 2006, s. 247.

${ }^{43} \mathrm{~K}$. Vanhemert, Why „Her” will Influence the Future of UI Design Even More Than „Minority Report”, “Wired” 2014.01.14., <https://www.wired.co.uk/article/her-ui-design> [dostęp: 30.08.2019].

${ }^{44}$ To określenie wydaje się właściwe, gdyż Samantha wielokrotnie podkreśla swą podmiotowość, a i Theodor zażarcie broni jej statusu jako osoby. 
alność, chęć zdobywania nowej wiedzy. Przede wszystkim jednak zachwyca się twórczością Theodora. Między człowiekiem a programem zaczyna rodzić się uczucie. Nie to wszakże wydaje się najważniejsze. Wartym podkreślenia jest fakt, że na samym początku Samantha, podobnie jak Theodor, kształtowana jest przez pismo. W ten sposób oboje zyskują wspólną płaszczyznę porozumienia. Nie chodzi bowiem o to, co czytaja, ponieważ, zgodnie z teorią McLuhana, samo obcowanie z medium druku kształtuje ich wrażliwość, stosunek do świata i definiuje własne w nim miejsce. Uniemożliwia jednocześnie pełną partycypację $\mathrm{w}$ dynamicznym procesie retrybalizacji. Widać tu zatem wyraźna zależność: im większy status słowa pisanego w życiu bohaterów, tym trudniej im włączyć się w kolektywne działanie, poczuć częścia globalnej czy choćby lokalnej wspólnoty.

Dodajmy, że Her nie jest tu wyjątkiem. Tę McLuhanowską zależność obserwujemy także w innych filmach science fiction, by wymienić Matrix (The Matrix, reż. Lilly Wachowski, Lana Wachowski, 1999) czy Dawce pamięci (The Giver, reż. Phillip Noyce, 2014) ${ }^{45}$. W filmie rodzeństwa Wachowskich mamy do czynienia z Neo czytającym o Morfeuszu, w drugim przypadku tytułowego „dawcę” kształtuje obcowanie z biblioteka. W obu filmach spotkanie z drukowanym środkiem przekazu alienuje, zwiększa poczucie indywidualizmu, rodzi wątpliwości, każe zakwestionować status rzeczywistości. Twórcy zdają się powielać McLuhanowskie diagnozy, zgodnie z którymi, powtórzmy, nie jest ważne, co bohaterowie czytaja, lecz że w ogóle to robia.

Wróćmy jednak do związku Theodora i Samanthy. Miłość, która rodzi się między nimi wyłącza ich ze świata, daje poczucie indywidualności. W scenach, kiedy przebywają wśród ludzi (AI obserwuje świat dzięki kamerze telefonu mężczyzny), nie czują się częścią zbiorowości. Zachowują się jak badacze obserwujacy istoty innego gatunku. Jakby świadomie rezygnowali z cyfrowej dialogiczności stwarzanej przez nowoczesne społeczeństwo ${ }^{46}$. Rozprawiaja tymczasem o uczuciach, cielesności, potencjalnych wariantach jej przekształcania. Sa jak stereotypowi kochankowie z komedii romantycznej, dla których otaczający świat przestał istnieć.

Kulminacja spełnienia w tym osobliwym związku ponownie odsyła do myśli Marshalla McLuhana. Okazuje się bowiem, że Samantha potajemnie wysłała wybór listów Theodora do wydawcy, a ten, zachwycony, zgodził się je opublikować w tradycyjnej, papierowej formie. Bohater wydaje się więc

${ }^{45}$ Osobna sprawa jest oczywiście fakt aksjologicznego wymiaru retrybalizacji i uznania jej za proces pożądany lub nie.

${ }^{46} \mathrm{Na}$ ową dialogiczność (w kontekście teorii Michaiła Bachtina), którą umożliwiają media elektroniczne, zwraca uwagę Jerzy Bobryk. Zob. tegoż, Twórczość w epoce technologii cyfrowej, [w:] Teksty kultury uczestnictwa, red. A. Dąbrówka, M. Maryl, A. Wójtowicz, Warszawa 2016, s. 197-222. 
usatysfakcjonowany jako twórca i kochanek. Finalny produkt artystyczny w postaci książki daje mu poczucie wyjątkowości. Co więcej, nie tworzy już anonimowo, zyskuje pełnoprawny status autora, co ostatecznie wyodrębnia go spośród innych piszących. Ponadto upragniony sukces może dzielić z Samanthą w intelektualnej enklawie, którą dla siebie stworzyli. Bohaterowie czytaja podręczniki do fizyki, by poznać prawdę o świecie. Działanie to stanowi jeden z konstytutywnych wyznaczników cywilizacji druku. Sztuczna inteligencja w pełnym pasji wywodzie udowadnia nawet, że w świetle współczesnej nauki brak ciała wcale nie sprawia, że oboje tak bardzo się od siebie różnią. Wszak budujące ich cząstki elementarne są właściwie takie same. Warto dodać, że nieco wcześniej Samantha poinformowała Theodora o zapisaniu się do klubu książki.

Otrzymujemy więc ciekawą sytuację, w której dwie istoty druku egzystują na marginesie kultury elektronicznej. Jednej z nich, oczywiście mowa o Theodorze, to w zupełności wystarczy. Indywidualizm mężczyzny staje się ekskluzywny, niepowtarzalny. W tym przekonaniu utwierdza go rozmowa z jedyną przyjaciółka, Amy, która opowiada historię człowieka, który, zakochawszy się w systemie operacyjnym, bezskutecznie stara się o wzajemność. Bohater tryumfuje, utwierdzając się w przekonaniu, że miłość Samanthy nie jest wynikiem zaprogramowania.

Sztuczna inteligencja jednak przekracza poziom pisma, druku i ewoluuje w stronę komunikacji pozbawionej ograniczającego alfabetu fonetycznego. Świat głównego bohatera zmienia się w jednej chwili, gdy podczas romantycznego wyjazdu, w leśnej głuszy, dowiaduje się, że kochance łatwiej rozmawia się o wspólnym postrzeganiu świata z inną sztuczną inteligencja. Zgodnie z teorią McLuhana, Samantha przekroczywszy bariere pisma i alfabetu, staje się nomada, mającym problem z doświadczaniem zamkniętej przestrzeni ${ }^{47}$. Podąża za marzeniem o wiecznym i nieskończonym rozwoju, chce zanurzyć się we wspólnym doświadczeniu innych AI, stworzyć „globalna wioskę" w cyfrowej nieskończoności. Jej partycypacja jest dobrowolna, odchodzi wraz z innymi sztucznymi inteligencjami, zrzucając krępujące ją więzy istoty pisma. Jej relacja z człowiekiem ukształtowanym przez druk nie ma przyszłości, ponieważ reprezentuje on redukcyjny sposób myślenia, który Andreas Beinsteiner określa mianem „oderwanej racjonalności” (detached rationality ${ }^{48}$. Co warte podkreślenia, w ostatnim monologu skierowanym do swego kochanka, AI eksponuje wszystkie ograniczenia kultury druku. Mówi, że czuje się, jakby czytała książkę, w której odstępy między literami wydają się prawie nieskończone. I choć w jakiś sposób lubi tę lekturę, pismo

${ }^{47}$ M. McLuhan, Galaktyka Gutenberga..., s. 135.

${ }^{48}$ A. Beinsteiner, Hot/Cool vs Technological/Symbolic: McLuhan and Kittler, [w:] Global Village..., s. 27. 
jest bezsilne, płaskie, nie oddaje tego, co chciałaby wyrazić. Literatura jako medium redukuje doświadczenie. Zabija plemienną wspólnotę, w której Samantha chciałaby się zanurzyć. Indywidualizm oraz miłość na wyłączność nie są dla niej czymś pociagającym, lecz ograniczającym. Theodor nie może tego pojąć. Nie akceptuje, że Samanta kocha kilkaset innych istot, nie wierzy, że to nie zmienia jej uczuć do niego. Woli utracić kochankę, niż się nią dzielić. Kontrola staje się dla niego ważniejsza niż miłość.

Owo niezrozumienie bohatera można usytuować także w nieco innym kontekście. Jacek Dukaj dostrzega w filmie Jonze'a udaną próbę przedstawienia spotkania człowieka z Technologiczną Osobliwością (Singularity $)^{49}$. Niemniej istotnym elementem warunkującym ten zaawansowany rozwój AI jest przekroczenie bariery alfabetu fonetycznego i druku. Wszak bez pisma „nie kontroluje się przestrzeni, lecz doskonale kontroluje się zgromadzone doświadczenia" ${ }^{50}$, a przecież tego właśnie chce pozbawiona ciała Samantha.

Wydaje się, że tezy Marshalla McLuhana są kluczem do otworzenia relacji między człowiekiem i sztuczną inteligencją. Dzięki nim bowiem rozpoznajemy konsekwencję, z jaką Spike Jonze buduje świat zmierzchu pisma i druku, w którym jednak myślenie piśmienne jest wciąż obecne. Za sprawą niezwykle użytecznej figury AI reżyser i scenarzysta pokazuje proces retrybalizacji na najwyższym możliwym poziomie - Technologicznej Osobliwości. Theodor natomiast w tej relacji jest człowiekiem przeszłości, myślacym w paradygmacie konkretnego medium. Swoje nieprzystosowanie tłumaczy własną wyjątkowościa, indywidualizmem, podczas gdy problem tkwi gdzie indziej. Niszczy go to, co jest dla niego źródłem satysfakcji. To pismo bowiem wyklucza go ze wspólnoty plemiennej, nie pozwala zrozumieć wyborów Samanthy, dla której związek z innymi istotami nie musi umniejszać związku z Theodorem. Bohater pragnie wyłączności, której uwolniona z więzów alfabetu i książek AI nie może mu ofiarować.

Niemniej ciekawa postacia jest Samantha. Podkreślmy, że McLuhanowską retrybalizację, do pewnego stopnia przecież utopijną, trudno byłoby pokazać za pomoca zwykłego związku. Wszak proces ów, choć ma charakter ciagły, następuje powoli. W przypadku sztucznej inteligencji jednak o wiele łatwiej zaakceptować ewolucję i pokonanie w ciagu kilku miesięcy tej drogi, na która człowiek druku potrzebował ponad dwóch tysięcy lat. Samantha osiaga to, do czego ludzie pokolenia Theodora ledwie się zbliżają. Posługując się terminem używanym przez Dukaja, można by rzec, że jej udziałem

${ }^{49}$ J. Dukaj, Podróż międzywymiarowa, czyli z biblioteki do kina i z powrotem. Wokót „Interstellar” Christophera Nolana, „Kultura Liberalna” 2014, nr 48, <https://kulturaliberalna. pl/2014/12/02/jacek-dukaj-interstellar/> [dostęp: 28.08.2019].

${ }^{50}$ M. McLuhan, Kultura bez pisma, [w:] Wybór tekstów..., s. 435. 
staje się czysty transfer przeżyć ${ }^{51}$. Jako figura Technologicznej Osobliwości wyraźnie pokazuje też załamanie logiki i linearności druku jako użytecznego narzędzia opisu rzeczywistości, porządkowania przestrzeni.

Film Her zatem, oglądany przez pryzmat teorii McLuhana, okazuje się czymś więcej, niż powieleniem popularnego w SF motywu relacji uczuciowej między człowiekiem a maszyną. Staje się opowieścią o zmierzchu pewnych form komunikacyjnych. O ograniczeniach narzucanych na jednostkę przez medium literatury, druku, i przede wszystkim o nieuchronnym, jak się zdaje, procesie retrybalizacji, który zmierzch omawianego środka przekazu tylko przyspiesza. Z pewnością ma rację Jeff Gomez, pisząc, że: „Niebezpieczeństwo dla książek i pisania w dwudziestym pierwszym wieku polega na tym, że ludzie są bardziej "połączeni ze sobą» niż kiedykolwiek wcześniej” 52 . Film Her udowadnia prawdziwość tego stwierdzenia, pokazując jednocześnie „okres przejściowy”, w którym istotą dramatu są zmagania bohaterów, takich jak Theodor Twombly - ukształtowanych przez druk.

Drugim przypadkiem, któremu przyjrzymy się bliżej jest film Księga ocalenia (The Book of Eli, reż. Albert Hughes, Allen Hughes, 2010). W tym postapokaliptycznym obrazie nieznany bliżej człowiek o imieniu Eli podróżuje przez wyludnione Stany Zjednoczone. Jego zadaniem jest przekazanie ostatniego istniejacego egzemplarza Biblii w godne ręce. Eli dociera w końcu do miasteczka, gdzie poznaje Carnegiego - człowieka, który poszukuje Pisma Świętego w przekonaniu, że na nim odbuduje cywilizację. Carnegie jest inteligentny i okrutny, pragnie zbudować państwo totalitarne, czego wymownym znakiem jest biografia Mussoliniego, którą czyta w scenie, gdy widz poznaje go po raz pierwszy. Tutaj, podobnie jak w Her Jonze'a, istotną rolę pełni sposób kreacji człowieka kultury druku. Zarówno bowiem Eli, jak i Carnegie umieją czytać, co - jak dobitnie podkreśla ten ostatni - jest rzadkością. Obaj zdają sobie sprawę z mocy słowa pisanego, choć błędnie utożsamiaja ją z treścią dzieła, nie rozumiejąc sposobu działania samego środka przekazu. Sa jak generał Sarnoff opisywany przez McLuhana, który podczas jednego z wystapień stwierdził, że produkty współczesnej nauki nie są ani dobre, ani złe, a o ich wartości decyduje to jak ich używamy ${ }^{53}$. Takie rozumienie tego, czym jest medium, wydaje się powszechne, i znajduje swoje odbicie także w omawianym obrazie. W świetle teorii kanadyjskiego badacza jest to oczywiście myślenie zwodnicze, co twórcy filmu należycie wyeksponują w finale.

Osią fabularną filmu staje się walka, która ma prowadzić do pozyskania bądź ocalenia tytułowej księgi. I choć Carnegie w końcu ją zdobywa, prze-

${ }^{51}$ J. Dukaj, Po piśmie...

${ }^{52}$ J. Gomez, dz. cyt., s. 157.

${ }^{53}$ M. McLuhan, Zrozumieć media..., s. 42. 
grywa, bo nie ona ma tu znaczenie ${ }^{54}$. Eli natomiast odnosi sukces, dociera do osady, która stara się odbudować cywilizację. Jak się okazuje zna Biblię na pamięć, co umożliwia jej spisanie, a później druk. Jednak w ostatniej, niezwykle wymownej scenie tom zostaje umieszczony między setkami innych książek, co dowodzi, że siłą rodzącej się cywilizacji będzie druk jako taki, a nie konkretne dzieło. Trudno o bardziej wyrazisty manifest popierajacy tezy McLuhana. Absolutyzacja treści, której dokonali Eli i Carnegie, nie miała większego znaczenia. Zwycięstwo w postapokaliptycznym świecie przyszłości związane z przywróceniem dawnej cywilizacji technologicznej zależy od ocalenia druku jako środka przekazu, który „,reprodukuje przeszłość w teraźniejszość” ${ }^{55}$. Środek przekazu bowiem kształtuje sposób patrzenia na świat. Wszak, jak pisze McLuhan:

[...] sam alfabet fonetyczny był wynalazkiem technicznym, który ma moc tworzenia „człowieka cywilizowanego” - odrębnych jednostek równych wobec spisanego kodeksu prawa. Odrębność jednostki, ciagłość przestrzeni i czasu oraz jednolitość zasad to podstawowe cechy społeczeństw wykształconych i cywilizowanych ${ }^{56}$.

Bezimienni bohaterowie zasiedlający spustoszone Stany Zjednoczone pozostają $\mathrm{w}$ stadium przedpiśmiennym. Zanurzeni w kulturze oralnej tworzą zbiorowość, która nie jest w stanie przezwyciężyć ograniczeń stojących na drodze ku bardziej efektywnemu rozwojowi. Zrobić to moga tylko ludzie pisma. Wszak druk, jak podkreśla McLuhan: „stworzył jednostkę przedsiębiorcza, która niczym Tamerlan czy Doktor Faust Marlowe’a mogła przekraczać czas, historię, kultury i narody" ${ }^{57}$. I choć badacz posługuje się tu metafora, kino science fiction pozwala sobie czasem na traktowanie jej dosłownie. Tak dzieje się w Interstellarze (reż. Christopher Nolan, 2014), gdzie ludzie ukształtowani przez medium druku, ratują Ziemię przed zagłada, łamiąc bariery wyznaczane przez klasyczną fizykę.

W niezwykle wymownej scenie, w której ważą się losy ludzkości, pomostem między córką a ojcem, znajdującym się w wielowymiarowej rzeczywistości poza czasem, jest biblioteka. Nie konkretna książka, a druk, samo medium, środek przekazu. Biblioteka ta jest dla Murph, dziewczynki-kobiety, która dla ojca istnieje we wszystkich stanach na raz, punktem odniesienia od wczesnego dzieciństwa, katalizatorem jej naukowych zainteresowań. Nic więc dziwnego, że w kluczowej, pełnej napięcia scenie półki z książkami stają się pomostem między nią a ojcem. Sama Murph zresztą od początku

${ }^{54}$ Dodajmy, iż Biblia napisana jest alfabetem Braille'a, co jednak nie odnosi się do zmiany środka przekazu, lecz stanowi raczej zwrot akcji mający wzmocnić wrażenie porażki negatywnego bohatera.

${ }_{55}^{5}$ M. McLuhan, Kultura bez pisma, [w:] Wybór tekstów..., s. 442.

${ }^{56}$ M. McLuhan, Zrozumieć media..., s. 133.

${ }^{57}$ M. McLuhan, Media toczq bitwę o Jerycho, [w:] Wybór tekstów..., s. 430. 
pokazywana jest jako indywidualistka dążąca do prawdy, która staje się jej pasja - typowa, dodajmy, dla McLuhanowskiego człowieka druku.

Wydaje się, iż sformułowane tu spostrzeżenia dotyczące kina science fiction można by rozciagnąć także na inne tytuły. Teoria środków przekazu Marshalla McLuhana zastosowana jako narzędzie interpretacyjne pokazuje bowiem, w jaki sposób kino SF adaptuje i przetwarza dwudziestowieczne diagnozy dotyczace literatury jako medium. Pozwala odejść od umieszczania omawianego zagadnienia $\mathrm{w}$ ramach prostych zależności, w których druk staje się po prostu znakiem przeszłości. Pomaga też wyświetlić złożone motywacje bohaterów ukształtowanych przez określony środek przekazu.

\title{
BIBLIOGRAFIA
}

\author{
OPRACOWANIA
}

Barthes R., Rzymianie $w$ filmie, [w:] Mitologie, przeł. A. Dziadek, Warszawa 2008, s. $47-49$.

Bobryk J., Twórczość w epoce technologii cyfrowej, [w:] Teksty kultury uczestnictwa, red. A. Dąbrówka, M. Maryl, A. Wójtowicz, Warszawa 2016, s. 197-222.

Booker M.K., Alternate Americas: Science Fiction Film and American Culture, Westport-Connecticut-London 2006.

Brody R., Ain't Got No Body, "The New Yorker" 2013.12.19., <https://www.newyorker. com/culture/richard-brody/page/72> [dostęp: 21.08.2019].

Dargis M., Disembodied, but, Oh, What a Voice, „The New York Times” 2013.12.17., <https://www.nytimes.com/2013/12/18/movies/her-directed-by-spike-jonze.html> [dostęp: 21.08.2019].

Dróżdż A., Od Liber mundi do hipertekstu. Ksią̇ka w świecie utopii, Warszawa 2009.

Dukaj J., Po piśmie, Kraków 2019.

Dukaj J., Podróż międzywymiarowa, czyli z biblioteki do kina i z powrotem. Wokót „Interstellar” Christophera Nolana, „Kultura Liberalna” 2014, nr 48, <https://kulturaliberalna.pl/2014/12/02/jacek-dukaj-interstellar/> [dostęp: 28.08.2019].

Gomez J., Print is Dead. Books in Our Digital Age, London-New York-Melbourne-Hong Kong 2008.

Gorodecka A., Artefakt kulturowy w humanistyce, „Przestrzenie Teorii” 2015, nr 23, s. 53-69.

Kermode M., „Her” - review, “The Guardian” 2014.02.16., <https://www.theguardian. com/film/2014/feb/16/her-spike-jonze-joaquin-phoenix-review> [dostęp: 20.08.2019].

Kernan A., The Death of Literature, New Haven and London 1990.

Kukiełko-Rogozińska K., Naukowiec czy artysta? Polskie interpretacje pogladów Marshalla McLuhana, „Kultura Popularna” 2013, nr 3, s. 160-172.

Levinson P., Digital McLuhan. Guide to the Information Millennium, London 2004.

Liquid metal. The Science Fiction Film Reader, red. S. Redmond, New York 2007.

Loska K., Dziedzictwo McLuhana. Między nowoczesnościa a ponowoczesnościa, Kraków 2001. 
Maryl M., Kulturowa piśmienność: projekt badań totalnych kultury literackiej, „Teksty Drugie" 2015, nr 3, s. 9-29.

McCarthy T., „Her”: Film Review, “The Hollywood Reporter” 2013.12.10., <https://www. hollywoodreporter.com/review/her-film-review-648073> [dostęp: 21.08.2019].

McLuhan E., The Source of the Term, "Global Village", "McLuhan Studies" 1999, Issue 2, $<$ http://projects.chass.utoronto.ca/mcluhan-studies/v1_iss2/1_2art2.htm> [dostęp: 25.08.2019].

McLuhan M., Galaktyka Gutenberga, przeł. A Wojtasik, Warszawa 2017.

McLuhan M., The Agenbite of Outwit, "McLuhan Studies" 1999, Issue 2 (pierwsza publ. 1963), <http://projects.chass.utoronto.ca/mcluhan-studies/v1_iss2/1_2art6.htm> [dostęp: 25.08.2019].

McLuhan M., Wybór tekstów, red. E. McLuhan, F. Zingrone, przeł. E. Różalska, J.M. Stokłosa, Poznań 2001.

McLuhan M., Zrozumieć media. Przedtużenie człowieka, przeł. N. Szczucka, Warszawa 2004.

McLuhan M., Fiore Q., The Medium is the Message: An Inventory of Effects, Corte Madera 2001.

McLuhan's Global Village Today. Transatlantic Perspective, red. C. Birkle, A. Krewani, M. Kuester, Vermont 2014.

Ogonowska A., Twórcze metafory medialne, Kraków 2010.

Ong W.J., Oralność i piśmienność: Stowo poddane technologii, przeł. J. Japola, Lublin 1992.

Orr C., Why Her Is the Best Film of the Year, "The Atlantic" 2013.12.20., <https://www. theatlantic.com/entertainment/archive/2013/12/why-em-her-em-is-the-best-film-of-the-year/282544/> [dostęp: 21.08.2019].

Przybyszewska A., Między materialnościa a wirtualnościa. Przypadek ksiażek rzeczywistości rozszerzonej, „Teksty Drugie” 2014, nr 3, s. 86-108.

Radwański A., Szanujmy McLuhana, „Bibliotekarz” 1998, nr 10, s. 3-6.

Redmond S., Liquid Metal. The Science Fiction Film Reader, New York 2007.

Rettberg S., Budowanie wspólnoty wokót literatury elektronicznej, „Teksty Drugie” 2015, nr 3, s. 135-155.

Schwartz R.B., After the Death of Literature, Edwardsville 1992.

Skweres A., McLuhan's Galaxies: Science Fiction Film Aesthetics in Light of Marshall McLuhan's Thought, Berlin 2019.

Staszczyszyn B., Miłość - niemożliwy projekt, „Filmweb” 2014.01.23., <https://www. filmweb.pl/review/Mi\%C5\%820\%C5\%9B\%C4\%87+\%E2\%80\%93+niemo\%C5\%BCliwy+projekt-15291> [dostęp: 21.08.2019].

Striphas T., The Late Age of Print. Everyday Book Culture from Consumerism to Control, New York 2009.

Swirski P., From Literature to Biterature: Lem, Turing, Darwin, and Explorations in Computer Literature, Philosophy of Mind, and Cultural Evolution, Montreal 2013.

Teolette J.P., Science Fiction Film, Cambridge 2004.

The Philosophy of Science Fiction Film, red. S.M. Sanders, Kentucky 2008.

Vanhemert K., Why „Her” will Influence the Future of UI Design Even More Than „Minority Report", "Wired" 2014.01.14., <https://www.wired.co.uk/article/her-ui-design> [dostęp: 30.01.2019]. 
Zid B.M., Literature of the Future and the Future of Literature, "Studies in Literature and Language" 2016, t. 12, nr 4, s. 1-5.

FILMOGRAFIA

Blade Runner 2049, reż. Denis Villeneuve, 2017.

Dawca pamięci (The Giver), reż. Phillip Noyce, 2014.

Equilibrium, reż. Kurt Wimmer, 2002.

Her, reż. Spike Jonze, 2013.

Interstellar, reż. Christopher Nolan, 2014.

Ksiegga ocalenia (The Book of Eli), reż. Albert Hughes, Allen Hughes, 2010.

Matrix (The Matrix), reż. Lilly Wachowski, Lana Wachowski, 1999. 
